\title{
Okul öncesi eğitim alan çocukların ve bulundukları sınıf ortamının yaratıcılık düzeyleri arasındaki ilişkisinin incelenmesi*
}

\author{
Examining the relationship between the creativity levels of the classroom \\ environment and the preschool children \\ Züleyha Yuvac1 ${ }^{1}$, H. Elif Dağlığlu ${ }^{2}$
}

\begin{abstract}
Makalale Geçmişi
Geliş : 12 Ocak 2018

Düzeltme : 12 Şubat 2018

Kabul : 20 Mart 2018
\end{abstract}

Makale Türü

Özgün Makale
Article History

Received : 12 January 2018

Revised : 12 February 2018

Accepted : 20 March 2018

Article Type

Original Article

\begin{abstract}
Öz: Bu çalışmada, Kayseri ili merkez ilçelerinde (Melikgazi, Kocasinan, Talas) bulunan altı yaş çocuklarına sunulan yaratıcı sınıf ortamlarının, çocukların yaratıcı düşünme becerileriyle ilişkisinin incelenmesi amaçlanmıştır. Araştırmanın çalışma grubunu, 51 öğretmen ve bu öğretmenlerin sınıflarında bulunan 357 çocuk oluşturmaktadır. Veri toplama aracı olarak öğretmenlere sınıflarındaki yaratıcı ortamı kaydetmeleri için "Okul Öncesi Yaratıcı Sınıf Ortamı Ölçeği” ve çocukların yaratıcılık düzeylerini belirlemek için "Hibrit Yaratıcılık Testi" uygulanmıştır. Araştırma sonuçları; çocukların yaratıcılıklarının orta düzeyde, öğretmenlerin görüşlerine dayalı olarak sınıf ortamının yaratıcılık düzeyinin ise oldukça yüksek düzeyde olduğunu göstermiştir. Sınıf ortamının yaratıcılık düzeyine ilişkin elde edilen sonucun öğretmenlerin ortamın yaratıcılık düzeyini yapay bir olumlulukla yüksek görmeye eğilimli olmalarından kaynaklandığı söylenebilir. Ayrıca okul öncesi eğitim kurumunda bulunan sınıfların ortamlarının yaratıcılık düzeyi ile çocukların yaratıcılık düzeyi arasında pozitif yönde ancak düşük düzeyde ilişki olduğu tespit edilmiştir. $\mathrm{Bu}$ bulgu, ögretmenlerin okul ortamını çocukların ilgi, yetenek, beceri ve gereksinimleri doğrultusunda gerekli yaratıcı özellikler taşıyacak şekilde düzenleyemediklerini ya da çocukların yaratıcılıklarını ortaya koymalarını sağlayacak özellikte etkinlikler organize etmede zorlandıklarını düşündürmüştür.
\end{abstract}

Anahtar Kelimeler: Okul öncesi dönem, Yaratıcı sınıf ortamı, Çocuk, Okul öncesi öğretmeni

Abstract: The aim of this study was to investigate the relationship between the creative classroom environments and the creative thinking skills of six-year old children in three central districts (Melikgazi, Kocasinan and Talas) of Kayseri province in Turkey. The participants of the study included 51 teachers and 357 students in their classes. The teachers who participated in this study were administered "the Pre-school Creative Classroom Environment Scale" for their perception of the level of creativity in their classes and the children were administered "the Integrated Creativity Test" to determine their level of creativity. The results of the research revealed that these children have a medium level creativity while the teachers' perception of the classroom environment for creativity was quite high. This discrepancy can be attributed to the teachers' tendency to evaluate their own classroom environments more positively for creativity. Still, a positive but low-level relationship was found between the creativity levels of the pre-school classroom environments and the creativity levels of the children. This finding suggests that teachers cannot always organize creative classroom environments in line with preschoolers' interests, abilities, skills and needs, or cannot organize activities that lead to children's use of their creativity in the classroom setting.

Keywords: Preschool period, Creative classroom environment, Child, Pre-school teacher

\footnotetext{
* Bu çalışma Züleyha Yuvacı'nın doktora tezinden üretilmiş ve 5.Uluslararası Okul Öncesi Eğitim Kongresinde “sözlü bildiri” olarak sunulmuştur.

${ }^{1}$ zuleyha.yvc@gmail.com

${ }^{2}$ Gazi Üniversitesi Gazi Eğitim Fakültesi Temel Eğitim Bölümü Okul Öncesi Eğitimi Anabilimdalı daglioglu1@gmail.com
} 


\section{SUMMARY}

\section{Introduction}

Children's interaction with their social environment is crucial for their creative thinking skills. One of these environments is the pre-school context where they gain most of their life-related experience. In this context what children are offered such as a wide range of materials, toys and creativity-oriented activities will help them think more distinctively and creatively. A free educational environment should be designed in such a way that children can work with different materials, and more of their nonconventional ideas are favored and encouraged so that their thinking and creativity are materialized (Aslan, Aktan and Kamaraj, 1997).

Classroom environment contributes to the development of children's personality, self-confidence, individuality and creativity, but at the same time it has the potential to leave positive or negative traces which may accompany their whole educational life (Alfuharg1, 2015; Özmenteş, 2012). Taking all these into consideration it can be contended that creativity education should start in early childhood (Gönen, Uzmen, Akçin \& Özdemir, 1993). Makhmalbaf and Yi-Luen Do (2007) conducted a research to analyze the impact of the physical environment on the level of children's creativity and found that rich materials, supplies and toys that children are provided in the classroom environment foster their creative thinking skills. Thus, children's educational environments play an important role in the development of their creative expressions (Fleith, 2000).

A number of studies on creativity can be listed (Akçum, 2005; Aslan, Aktan, \& Kamaraj, 1997; Alfuhaıg1, 2015; Aral, Köksal Akyol, \& Sığırtmaç, 2006; Ceylan, 2008; Çakmak, 2005; Çakmak \& Baran, 2005; Dinçer, 1993; Dursun \& Ünüvar, 2011; Makhmalbaf, \& Yi-Luen Do, 2007; Yapıc1, 2002; Yaşar, 2009; Yaşar \& Aral, 2010; Yaşar \& Aral, 2011). While some of these studies focus on the scope of creativity and what needs to be done to improve creative thinking (Summak \& Aydın, 2011, p.365), others examine different variables related to creative thinking (Kara, 2007; Palandökenlier, 2008; Yaşar $\&$ Aral, 2011) as well as the views of teachers on creative thinking (Ekici, 2014; Yıdırım, 2006).

\section{Method}

As this study aimed to investigate the relationship between the creative classroom environments provided for 6-year old children (60-72 months) and their creative thinking skills, it can be considered as an example of survey research for relationship. The participants of the study included 51 teachers and 357 students in their classes. The teachers were given the "Pre-school Creative Classroom Environment Scale" (Yuvac1, 2017) in order to identify their perception of creativity in their own classrooms. Preschool Creative Classroom Environment Scale is a four-point Likert Scale (Always, Usually, 
Sometimes, Never) survey instrument with five sub-sections and 47 items under them. In accordance with the expert opinions obtained for content validity, the instrument was developed and later piloted with 246 pre-school teachers after the necessary permission was obtained from Kayseri Provincial Directorate of National Education. The reliability of the instrument was also obtained running Cronbach's Alpha reliability coefficient, and it was found to be 0.931 . The students were administered the Integrated Creativity Test for Preschoolers (Creative Thinking Ability Section) developed by Lee and Lee (2002) and adapted and translated into Turkish by Yuvac1 (2017). It was first piloted with 50 preschool children for its reliability and validity. In order to determine the level of reliability of the scores gained by these children for the sub-skills of imagination, flexibility, fluency, originality, continuation, completion, new elements, theme and unconventionality, a Cronbach's Alpha reliability coefficient was run, and it was found to be 0,837 . The data obtained by using these two survey instruments were first transferred to SPSS version 20.0 files. Then, the necessary statistical tests were run in accordance with the research questions of the study.

\section{Conclusion and Discussion}

Within the scope of this study, the relationship between the creativity level of preschool children and the creative classroom environments was investigated. One of noticeable results of the study is that the children attending preschool level education have medium level creativity in general. Regarding the sub-skills of the Integrated Creativity Test, the children had the highest scores for fluency and imagination. These two were followed by completion, new elements, continuation, theme and flexibility. On the other hand, the children's creativity levels were found to be the lowest for originality and unconventionality. Such a result may be attributed to some teachers' tendency to limit all the children in a class to use the same material for the same task only, and even to reorient those students who may come up with an original outcome back to the required task.

Another result of the study is that the teachers who participated in this study think level of creativity in their classrooms is quite high. Regarding the sub-dimensions of the Scale, the teachers think that creativity is mostly encouraged in the dimensions of respecting children, giving importance to their ideas, activating them, environments/contexts and centers, respectively. Even though the teachers give the least importance to the dimensions of environments/contexts and centers, they seem to have a tendency to overstate the level of creativity in the classroom environment in general. The relationship between the creativity level of the classroom environment in pre-schools and the children's level of creativity was found to be positive but at a low level. The findings show that creative classroom environments affect children's level of creativity in a positive way but at a low level. In line with these results, based on the teachers' perceptions, it can be stated that the high creativity level in the classroom environment does not always reflect to children's creativity in reality. In order to have a better match between what teachers think and what happens in reality with children, it can be suggested teachers get 
together especially during the seminars to discuss good models of creativity activities and creative classroom environments and organize workshops. In addition to survey instruments that are used to collect data for children's and teachers' opinions and performances, objective classroom observations should also be included in the studies investigating creative classroom environments. 


\section{GİRIŞ}

Çocukların, çok erken dönemden itibaren yakın çevresiyle kurduğu nitelikli etkileşim, onu yaşama hazırlamakla birlikte aynı zamanda da davranışlarını, tutumunu ve düşünme yapısını etkilemektedir. Çocuğun farklı, orijinal, üretmeye elverişli ve nitelikli düşünmesine ve ileriki yaşamına sağlam adımlar atmasına yardımcı olan ortamlardan biri aile ortamıdır. Anne-babanın çocuğa karşı tutumu, ortamda bulunan zengin öğrenme materyalleri, çocukların düşüncelerini rahatlıkla ifade etme imkanı; çocuğun farklı düşünmesi, üretmesi ve hayal etmesine yardımcı olacak yaratıcı düşünme ortamı oluşturmak için son derece önemlidir (Kemple \& Nissenberg, 2000).

Çocuğun gelişim serüveninde aileden sonra onun yaratıcı düşünme becerilerini olumlu yönde etkileyen önemli çevrelerden biri de sınıf ortamıdır. Sınıf ortamı çocuğun kişilik, özgüven, özgünlük ve yaratıcılık gelişimine destek olmakla birlikte bütün eğitim hayatına eşlik edebilecek olumlu ya da olumsuz izler bırakabilecek güce sahiptir (Alfuhaıg1, 2015; Özmenteş, 2012). Bütün bunlar dikkate alındığında yaratıcı nesiller yetiştirebilmek için, yaratıcılık eğitimine erken çocukluk döneminde başlamak gerektiği ortaya çıkmaktadır (Gönen, Uzmen, Akçin \& Özdemir, 1993). Bu bağlamda Makhmalbaf ve Yi-Luen Do (2007) yaptıkları araştırmada, çocukların bulunduğu fiziksel çevrenin yaratıcılıkları üzerine etkisini incelediği araştırma sonucunda çocuklara sınıf ortamında sunulan zengin materyal, malzeme ve oyuncaklar yoluyla onların yaratıcı düşüncelerinin beslendiği belirlenmiştir. Dolayısıyla çocukların bulundukları eğitim ortamları, çocukların yaratıcı ifadelerinin gelişmesinde önemli bir rol oynamaktadır (Fleith, 2000).

Çocuğun sosyal ortamı ile kurduğu etkileşim, yaratıcı düşünme becerilerinin gelişiminde oldukça önemlidir. Bu sosyal ortamlardan biri olan okul öncesi eğitim kurumunda çocuğa sunulan zenginleştirilmiş eğitim ortamları ve yaratıcı programlar onun özgün ve yaratıcı düşünmesini de sağlayabilmektedir. Kaliteli hazırlanmış yaratıcılık programları ile bütünleştirilmiş okul öncesi eğitim, çocukların daha sonraki akademik gelişimlerinin (Collins, O’Connor \& McClowry, 2017; Duncan vd., 2007; Rimm-Kaufman \& Pianta, 2000) temelini atmakta oldukça önemlidir. Hazırlanan programın uygulanması sırasında da özgür bir eğitim ortamında, çocuğun değişik materyaller ile çalışabileceği, düşüncelerinin ve yaratıcılığının ortaya çıkabilmesi için alışılagelmiş düşünce yerine alış1lagelmemiş düşüncenin desteklenmesi yaratıcılık eğitiminin önemli bileşenlenlerindendir (Aslan, Aktan ve Kamaraj, 1997).

Buradan hareketle çocuk, bu ortamda problemlerle karşılaşarak bu problemlere farklı çözüm yolları bulmayı öğrenebilmektedir. Dolayısıyla eğitim ortamları ancak çocukların kendini rahat 
hissedebilecekleri, bir problem olduğunda onu anlayıp sorunun farkına varmalarına ve buna ilişkin denenceler kurmalarına firsat verecek şekilde düzenlendiğinde, onların yaratıcı tutum ve davranışlarını geliştirebilmektedir (Özerbaş, 2011).

Yaratıcılıkla ilgili Türkiye'de yapılan araştırmalara bakıldığında bir çok çalışmaya rastlamak mümkündür (Akçum, 2005; Aslan, Aktan ve Kamaraj, 1997; Aral, Köksal Akyol ve Sığırtmaç, 2006; Ceylan, 2008; Çakmak, 2005; Çakmak ve Baran, 2005; Dinçer, 1993; Dursun ve Ünüvar, 2011; Yapıc1, 2002; Yaşar, 2009; Yaşar ve Aral, 2010; Yaşar ve Aral, 2011). Bu çalışmaların bir kısmı yaratıcılığın kapsamı ve yaratıcı düşünmeyi geliştirmek için yapılması gerekenler üzerine odaklanırken (Summak ve Aydın, 2011) bir kısmı ise yaratıcı düşünmenin farklı değişkenlerini irdelemekte (Kara, 2007; Palandökenlier, 2008; Yaşar ve Aral, 2011) ve yaratıcı düşünme ile ilgili öğretmen görüşlerini incelemektedir (Ekici, 2014; Yıdırım, 2006).

Alanyazın yaratıcı ortamlar ile çocukların yaratıcı düşünme becerileri arasındaki ilişkiyi inceleyen çalışmalar açısından incelendiğinde ise Türkiye'de ve dünyada çok az çalışmaya rastlanmaktadır. Varolan çalışmalara bakıldığında, Makhmalbaf ve Yi-Luen Do'nun (2007) çocukların bulunduğu fiziksel çevrenin onların yaratıcılıklarının gelişimindeki rolünü incelediği; Alfuhaıgı'nin (2015) okul çevresinin ve yaratıcılığın çocuğun gelişimi üzerine etkisini inceleyen araştırmaları derlediği; Kim ve Koo Lee'nin (2015), yaratıcı ev ortamı ve yaratıcı kişilik özelliklerinin küçük çocukların duygusal zekâları üzerindeki etkisini incelediği; Sharma'nın (2016) çocukların yaratıcı düşünme gelişiminde ev ve okul ortamlarının etkisini yüksek ve düşük sosyoekonomik düzey bazında incelediği; Leggett'in (2017) erken öğrenme ortamlarında bulunan öğretmenlerin, öğretmen olarak rollerinin çocukların yaratıcılıkları üzerindeki etkisini inceleyen son araştırmaları derlediği; Lew ve Cho'nun (2013) küçük çocukların motivasyonu ve yaratıcı ev ortamları ile yaratıcılıkları arasındaki ilişkiyi araştırdığı; Oh ve Choi'nin (2006), Okul Öncesi Çocuklar için Yaratıcı Ev Ortamı Ölçeği’ni geliştirdiği görülmektedir. Türkiye'de yapılan çalışmalar incelendiğinde ise, Kara'nın (2007) okul öncesi dönemde 5-6 yaş grubu çocukların yaratıcılık düzeylerini etkileyen faktörlere ilişkin öğretmen görüşlerini incelediği çalışma ile birlikte Özerbaş'ın (2011) yaratıcı düşünme yöntemine uygun olarak tasarlanmış öğrenme ortamının, öğrenci akademik başarısına ve başarının kalıcılığına etkisini incelediği çalışmalar karşımıza çıkmaktadır.

Sonuç olarak, çocuklara zengin çevre olanakları sunulmasının onların gelişimlerini olumlu yönde etkilediği, Türkiye'de ve dünyada bu tip yaratıcı çevre oluşturma ile ilgili çalışmalara ihtiyaç duyulduğu görülmektedir. Dolayısıyla bu araştırma, özellikle okul öncesi dönem 
çocuklarına sunulan ortamların, onların yaratıcılıklarına ne düzeyde hizmet ettiğini incelemek amacıyla planlanmıştır. Buradan yola çıkarak, aşağıdaki sorular belirlenmiştir:

Öğretmenlerin görüşlerine göre okul öncesi dönem çocuklarının devam ettikleri sınıf ortamının yaratıcılık düzeyi nedir?

Okul öncesi eğitim kurumlarına devam eden 6 yaş grubu çocukların yaratıcı düşünme becerileri ne düzeydedir?

Okul öncesi eğitim kurumuna devam eden çocukların yaratıcı düşünme düzeyleri ile sınıf ortamlarının yaratıcılık düzeyi arasında nasıl bir ilişki vardır?

\section{YÖNTEM}

\section{Araştırmanın Modeli}

Bu çalışmada, Kayseri ili merkez ilçelerinde (Melikgazi, Kocasinan, Talas) bulunan altı yaş çocuklarına sunulan yaratıcı sınıf ortamlarının, çocukların yaratıcı düşünme becerilerini ne derece etkilediğini belirlemek üzere Okul Öncesi Yaratıcı Sınıf Ortamı ölçeği ve Hibrit Yaratıcılık testi uygulanmıştır. Çalışmada, altı yaş (60-72 ay) çocuklarına sunulan yaratıcı sınıf ortamları ile çocukların yaratıcı düşünme becerileri arasındaki ilişkisinin incelenmesi amaçlandığından araştırma genel tarama desenlerinden ilişkisel tarama desenine göre dizayn edilmiştir. Tarama desenleri, çok sayıda elemandan oluşan bir evrende, evren hakkında genel bir yargıya varmak amacı ile, evrenin tümü ya da ondan alınacak bir grup örnek ya da örneklem üzerinde yapılan araştırmalardır (Karasar, 2002).

\section{Çalışma Grubu}

Araştırmanın çalışma grubunu Kayseri ili merkez ilçelerindeki (Melikgazi, Kocasinan, Talas) MEB'a bağlı devlet okullarından bağımsız okul öncesi eğitim kurumları ve ilköğretim okulları bünyesindeki anasınıflarında görev yapan 51 öğretmen ve bu öğretmenlerin sınıflarında bulunan 6 yaş grubu 357 çocuk oluşturmaktadır.

Tablo 1. Araştırmaya katılan çocukların demografik özellikleri

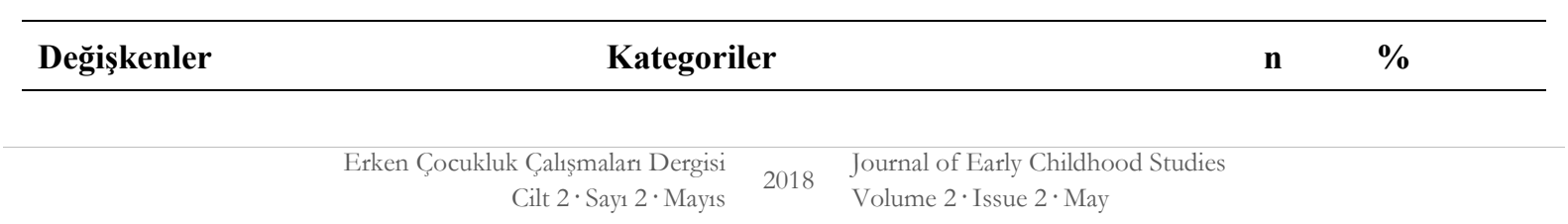




\begin{tabular}{|c|c|c|c|}
\hline & Kocasinan & 145 & 40,6 \\
\hline \multirow[t]{2}{*}{ Yaşadığı ilçe } & Melikgazi & 150 & 42,0 \\
\hline & Talas & 62 & 17,4 \\
\hline \multirow{2}{*}{ Cinsiyet } & Erkek & 200 & 56,0 \\
\hline & Kiz & 157 & 44,0 \\
\hline \multirow{3}{*}{ Yaş } & 64-68 ay & 79 & 22,1 \\
\hline & $69-70$ ay & 167 & 46,8 \\
\hline & $71-74$ ay & 111 & 31,1 \\
\hline \multirow{3}{*}{ Kardeş sayısı } & Tek çocuk & 104 & 29,1 \\
\hline & 1 kardeş & 191 & 53,5 \\
\hline & 2 ve daha fazla kardeş & 62 & 17,4 \\
\hline \multirow{3}{*}{ Doğum sırası } & İlk çocuk & 205 & 57,4 \\
\hline & İkinci çocuk & 128 & 35,9 \\
\hline & Üçüncü ve daha sonraki çocuk & 24 & 6,7 \\
\hline \multirow{2}{*}{ Okul öncesi eğitime devam etme süresi } & $1 \mathrm{y} 1 \mathrm{l}$ & 233 & 65,3 \\
\hline & 2 yil & 124 & 34,7 \\
\hline
\end{tabular}

Tablo 1 incelendiğinde araştırmaya katılan çocukların \%40,6'sı Kocasinan \%42'si Melikgazi ve \%17,4'ü Talas bölgesinde bulunmaktadır. \%56'sı erkek \%44'ü ise kızdır. Çocukların okul öncesi eğitime devam etme süresine bakıldığında \% 65,3'ünün 1 yıldır okul öncesi eğitim almakta olduğu ve \%57,4'ünün ilk çocuk \%35,9'unun ikinci çocuk olduğu görülmektedir.

Tablo 2. Örneklemdeki çocukların ögretmenlerinin demografik özelliklerine göre dağıllmı (frekans ve yüzde değerleri)

\begin{tabular}{|c|c|c|c|}
\hline Değişkenler & Kategoriler & $\mathbf{n}$ & $\%$ \\
\hline Cinsiyeti & Kadın & 51 & 100,0 \\
\hline \multirow{2}{*}{ Medeni durumu } & Evli & 36 & 70,6 \\
\hline & Bekâr & 15 & 29,4 \\
\hline \multirow{2}{*}{ Yaş1 } & $20-30$ & 21 & 41,2 \\
\hline & 31 ve üzeri & 30 & 58,8 \\
\hline \multirow{2}{*}{ Öğrenim durumu } & Üniversite & 50 & 98,0 \\
\hline & Yüksek lisans & 1 & 2,0 \\
\hline \multirow{2}{*}{ Çalıştı̆ğ okul türü } & Anasınıfi & 23 & 45,1 \\
\hline & Bağımsız anaokulu & 28 & 54,9 \\
\hline Kıdemi & $0-5$ y1l & 12 & 23,5 \\
\hline
\end{tabular}


6-10 y1l

11 yıl ve üzeri
$14 \quad 27,5$

Tablo 2 incelendiğinde araştırmaya katılan öğretmenlerin tümünün kadın ve üniversite mezunu olduğu belirlenmiştir. Katılımcıların çoğunun evli $(\% 70,6), 6-10$ yıl $(\% 49,0)$, ile 11 y1l ve üzerinde $(\% 47,1)$ kıdeme sahip olduğu saptanmıştır.

\section{Veri Toplama Araçları}

Araştırmada veri toplama aracı olarak Demografik Bilgi Formu, Okul Öncesi Yaratıcı Sınıf Ortamı Ölçeği ve Hibrit Yaratıcılık Testi kullanılmıştır.

\section{Demografik Bilgi Formu}

Araştırmacılar tarafından okul öncesi eğitim kurumuna devam eden çocukların demografik özelliklerinin belirlenmesi amacıyla çocukların yaşları, cinsiyetleri, kardeş sayıları, doğum sıraları, okul öncesi eğitime devam etme süreleri gibi bilgilerinin yer aldığı çocuk bilgi formu hazırlanmıştır. Bu form Hibrit Yaratıcılık Testine eklenmiş ve çocukların aileleri tarafından doldurulmuştur.

Ayrıca araştırma kapsamında çocukların ve öğretmenlerinin özelliklerinin tespit edilmesi amacıyla okul öncesi öğretmenlerinin cinsiyetleri, medeni durumları, yaşları, eğitim durumları gibi bilgilerin yer aldığı öğretmen bilgi formu hazırlanmıştır. Bu form Yaratıcı Sınıf Ortamı ölçeğine eklenmiş ve öğretmenler tarafından doldurulmuştur.

\section{Okul Öncesi Yaratıcı Sınıf Ortamı Ölçeği}

$\mathrm{Bu}$ ölçek Yuvacı (2017) tarafından geliştirilmiştir. Ölçek geliştirme sürecinde, ölçek maddelerinin kontrolü için iki ölçme ve değerlendirme, altı alan uzmanı ve bir Türkçe dil uzmanı olmak üzere toplam dokuz uzman belirlenmiş ve maddeler bu kişiler tarafından araştırmanın amacına uygunluk, maddelerin açıklığı ve anlaşılırlığı bakımından değerlendirilmiştir. Kapsam geçerliliği için uzmanlardan gelen görüşler doğrultusunda beş boyut ve 47 maddeden oluşan taslak ölçek, 246 okul öncesi öğretmenine Kayseri İl Milli Eğitim Müdürlüğü'nden gerekli izinler alınarak uygulanmış ve yapılan istatistiksel analizler sonucunda ölçekten çıkarılan 18 madde sonrasında kalan 29 maddenin dört boyutta toplandığı ve toplam 
varyansın \%57,438'ini açıkladığı belirlenmiştir. Bu doğrultuda geliştirilen ölçeğin yap1 geçerliğinin sağlandığı ön görülmektedir.

Okul Öncesi Yaratıcı Sınıf Ortamı Ölçeği’nin nihai formunda kalan maddelerin geçerlik düzeylerinin tespit edilmesi amacıyla düzeltilmiş madde-toplam korelasyonları hesaplanmıştır. $\mathrm{Bu}$ doğrultuda aktif hale getirme, ortam ve merkezler, saygı duyma, fikirlere önem verme alt boyutlarındaki maddelerin düzeltilmiş madde-toplam korelasyon katsayılarının 0,468 ile 0,750 arasında değiş̧iklik gösterdiği saptanmıştır. Bu doğrultuda ölçekte yer alan tüm maddelerin ait oldukları boyutu iyi derecede ayırt ettiği ortaya çıkmıştır. Ayrıca ölçme aracının güvenirliği için Cronbach Alfa güvenirlik katsayısı ele alınmış ve güvenirlik katsayısı 0.931 olarak hesaplanmıştır.

Gerçekleştirilen ölçeğin Açımlayıcı Faktör Analizi (AFA) ve Doğrulayıcı Faktör Analizi (DFA) yapılmıştır. Ölçek, 29 maddeden ve (1) Aktif Hale Getirme (12 madde), (2) Ortam ve Merkezler (8 madde), (3) Saygı Duyma (6 madde), (4) Fikirlere Önem Verme (3 madde) olmak üzere dört alt boyuttan oluşan, dörtlü likert (Her zaman, Çoğu Zaman, Ara Sıra, Hiçbir Zaman) tipi bir ölçme aracıdır. Ölçekten alınan puanlar arttıkça sınıf ortamının yaratıcılık düzeyinin yükseldiğini göstermektedir.

\section{Hibrit Yaratıcılık Testi}

Hibrit Yaratıcılık Testi (Integrated Creative Test for Preschooler- ICT-P- Creative Thinking Ability Section) Lee ve Lee (2002) tarafından geliştirilmiştir. Bu test yaratıcı düşünme yeteneği ve yaratıcı kişilik olarak iki bölümden oluşmaktadır. "Hibrit Yaratıcılık Testi (HYT)"nin yaratıcı düşünme ile ilgili bölümünün Türkçeye uyarlama çalışması Yuvacı (2017) tarafından yapılmıştır. Yaratıcı düşünme yeteneğinin, dil ve çizim alanı olmak üzere iki alt alanı bulunmaktadır. Dil alanı; imgelem, akıcılık, esneklik ve özgünlük faktörlerinden; çizim alanı; süreklilik, bağımlılık, tamamlama, yeni elemanlar ekleme, tema ve alışılmadıklık faktörlerinden oluşmaktadır.

Testin Türkçeye uyarlanma sürecinde, ölçek maddeleri öncelikle İngilizce dil uzmanlarından oluşan altı kişilik çeviri grubu tarafından önce İngilizceden Türkçeye çevirmiş, ardından geri çeviri tekniği ile Türkçeden İngilizceye çevirilmiştir. Test maddelerindeki taslak çevirilerin tamamlanmasının ardından İngilizce eğitimi bölümünde görev yapan toplam altı öğretim üyesinin görüşleri alınarak gerekli düzeltmeler yapılmıştır. Çevirileri gerçekleştirilen ifadelerin 
okul öncesi dönem çocuklarına uygunluklarının tespit edilmesi amacıyla okul öncesi eğitimi bölümünde görev yapan altı öğretim üyesinin görüşleri alınmıştır. Alan uzmanlarının görüşleri doğrultusunda testte son düzeltmeler yapılmıştır.

Çevirisi tamamlanan test, beş okul öncesi dönem çocuğuna uygulanmıştır. Dil alanına yönelik etkinlikler imgelem, akıcılık, esneklik ve özgünlük; çizim alanındaki aktiviteler süreklilik bağlılık, tamamlama, yeni eleman ekleme, tema ve alışılgelmemiş boyut kategorilerinde puanlanmıştır. Puanlamayı araştırmacı dışında okul öncesi eğitimi bölümünde görev yapan beş öğretim üyesi daha yapmıştır. Testte puanlayıcılar arasındaki güvenirlik düzeyi, Miles ve Huberman (1994) tarafından belirtilen "uyuşum yüzdesi” eşitlik ile hesaplanmıştır. Beş konu alan uzmanı testte yer alan dil ve çizim alanda bulunan toplam 11 faktör üzerinde inceleme gerçekleştirmiştir. $\mathrm{Bu}$ faktörlere yönelik uyuşum yüzdesi 0.74-0.97 arasında olduğu bulunmuştur. Uygulamaları tamamlanan test, geçerlik ve güvenirlik çalışması kapsamında okul öncesi eğitim kurumuna devam eden 50 çocuğa uygulanmıştır.

Hibrit Yaratıcılık Testi’nin yapı geçerliğinin belirlenmesi amacıyla gerçekleştirilen doğrulayıcı faktör analizi sonucunda hesaplanan regresyon katsayıları ve $t$ değerleri okul öncesi dönem çocuklarının yaratıcı yetenek düzeylerinin en çok tema $\left(R^{2}=0,58 ; p<0,05\right)$ daha sonra sırasıyla imgelem $\left(R^{2}=0,56 ; p<0,05\right)$, alış1lagelmemiş boyut $\left(R^{2}=0,56 ; p<0,05\right)$, süreklilik $\left(R^{2}=0,48\right.$; $\mathrm{p}<0,05)$, akıcılık $\left(\mathrm{R}^{2}=0,43 ; \mathrm{p}<0,05\right)$, yeni eleman ekleme $\left(\mathrm{R}^{2}=0,43 ; \mathrm{p}<0,05\right)$, özgünlük $\left(\mathrm{R}^{2}=0,42 ; \quad \mathrm{p}<0,05\right), \quad$ tamamlama $\quad\left(\mathrm{R}^{2}=0,32 ; \quad \mathrm{p}<0,05\right)$ düzeyleri tarafından açıklandı $\breve{g}_{1}$ belirlenmiştir.

Okul öncesi dönem çocukları ile gerçekleştirilen ön uygulama sonucunda çocukların cevapları doğrultusunda oluşturulan modelde, model-veri uyumunun değerlendirilmesi amaçlanmıştır. Doğrulayıcı Faktör Analizinde modelin geçerliliğini değerlendirmek için çok sayıda uyum indeksi kullanılarak yapılan analiz sonucunda Hibrit Yaratıcılık Testi'nin kabul edilebilir uyum aralıkları arasında olduğu belirlenmiştir (X2/sd: 2.21 RMSEA: 0,087, CFI: 0,90, NFI: 0,90, GFI: 0,91). Bu bilgiler doğrultusunda çocukların yaratıcılık yeteneklerinin Hibrit Yaratıcılık Testi'nde yer alan alt yeteneklerle ölçülebileceği belirlenmiştir.

Hibrit Yaratıcılık Testi'nde yer alan imgelem, esneklik, akıc1lı, özgünlük, süreklilik, tamamlama, yeni eleman ekleme, tema ve alışıla gelmemiş boyut alt yeteneklerinden okul öncesi dönem çocuklarının almış oldukları puanların güvenirliğinin belirlenmesi amacıyla Cronbach alfa güvenirlik katsayısı hesaplanmıştır. Hesaplama sonucunda güvenirlik katsayısı 
0,837 olarak bulunmuştur. Bu sonuçlar, Hibrit Yaratıcılık Testi'nin geçerli ve güvenilir bir ölçme aracı olduğunu göstermektedir.

Hibrit Yaratıcılık Testi'nin puanlama ölçütleri incelendiğinde testin yapısına paralel olarak iki alanda puanlama yapıldığı görülmektedir. Yaratıcılığın, dil alanı dahilindeki alt faktörleri; imgelem, akıcılık, esneklik ve özgünlük olmak üzere dört faktörden oluşmaktadır. Her bir alt faktör için farklı bir puanlama sistemi mevcuttur. Bunlar İmgelem boyutunda, gerçek bir duruma dayanarak genişletilmiş hayali düşüncelerin her biri için puan verilmektedir. Akıcılık boyutu için, özel bir duruma ilişkin olarak problem çözmek için kullanılan düşünce ve yöntemlerin sayısı puanlanmaktadır. Esneklikte ise puan, verilen cevap sayısına göre verilmektedir. Özgünlük boyutu için, çocuk geleneksel düşünceden uzaklaşıp, özgün ve yenilikçi fikirler oluşturduğunda genel puanlamaya bir puan eklenmektedir. Çizim alanı, bir maddeden oluşmaktadır. Çizim alanının alt faktörleri; süreklilik ve bağlılık, tamamlama, yeni elemanlar ekleme, tema ve alışlagelmemiş boyut olmak üzere toplam altı alt faktörden oluşmaktadır. Çocuğun yaptığı çizim her bir alt boyut için ayrı ayrı değerlendirilmektedir. Çocuğun aldığı puan ve puanlamalar yaptığı resmin ayrıntılarına göre değişmektedir.

\section{Veri Toplama Süreci}

Araştırmanın uygulaması 2016-2017 eğitim öğretimin güz döneminde yapılmıştır. HYT, 357 çocuğa uygulanırken Yaratıcı Sınıf Ortamı Ölçeği bu çocukların öğretmeni olan 51 kişiye uygulanmıştır. Uygulamalar Kocasinan, Melikgazi ve Talas ilçelerinden ilçe büyüklügüne göre sınıf sayıları belirlenmiştir. Bu ilçelerdeki deneme uygulamasına katılmayan öğretmen ve çocuklar arasından amaçlı örnekleme yöntemi ile seçilerek araştırmaya dahil edilmiştir. Örnekleme dahil edilen çocukların yaşının 60-72 ay arasında olmasına ve öğretmen tarafından normal gelişim gösterdiği belirtilmesine, cinsiyet dengesine ve her öğretmenin sınıfından en fazla yedi çocuk olmasına dikkat edilerek seçilmiştir. Uygulamalar 2016-2017 eğitim-öğretim yılının güz döneminde çocukların okula alışma dönemi tamamlandıktan sonra kasım ayından itibaren haftada üç gün olacak şekilde yapılmıştır. Uygulama mekanları okulların fiziki durumlarına bağlı olarak belirlenmiştir. Fiziksel şartları uygun olan okullarda ayrı bir odada, ayrı odası olmayan okullarda ise uygun olan bir müdür yardımcısı ya da rehber öğretmenin odasında aşağıda belirtilen yönergeler ve şartlar doğrultusunda HYT uygulanmıştır. Araştırmacı teste "Merhaba benim ismim........, sana sözcükler, rakamlar ve şekiller ile ilgili ĕ̆lenceli sorular soracă̆ım. Seninle yapacağımız bu etkinliklerin doğru ya da yanlış bir cevabı yok. Bazı sorular sana ilginç gelebilir. Bu soruları düşünürken keyif alacağını düşünüyorum. 
Soruları istediğin gibi cevaplayabilirsin" yönergesi ile dil alanında bulunan hikayeler çocuklara okunarak çocukların verdikleri cevaplar araştırmacı tarafından kaydedilmiştir. Çizim alanı olan son kısımda ise çocuklara "Burada beş tane çizgi var. Bu çizgilerden bir resim yapmak isteseydin nasıl bir resim yapardın?" "İstediğin kalemi kullanip istediğin resmi yapabilirsin." şeklinde bir yönerge kullanmıştır. Okula çocuklara ve öğretmenlere numaralar verilerek kodlamalar yapılmıştır.

\section{Verilerin Analizi}

Veriler öncelikle SPSS 20.0 paket programına aktarılmıştır. Ardından da araştırmanın problemleri doğrultusunda istatistikler hesaplanmıştır. Farklılık için $\mathrm{p}<0,05$ anlamlılık değeri kullanılmış ve sonuçlar tablolaştırılarak yorumlanmıştır.

\section{BULGULAR ve TARTIŞMA}

$\mathrm{Bu}$ bölümde, yöntem bölümünde açıklanan verilerin toplanması ve analizi ile elde edilen bulgular verilmekte ve araştırma soruları doğrultusunda sıralanarak yorumlanmaktadır.

Araştırmaya katılan okul öncesi d-önem çocuklarının eğitim kurumundaki yaratıcı ortamlarını belirlemek amacıyla Yuvacı (2017) tarafından geliştirilen ve dört boyuttan oluşan Okul Öncesi Yaratıcı Sınıf Ortamı Ölçeği, çocukların öğretmenlerine uygulanmıştır. Öğretmenlerin cevapları doğrultusunda betimsel istatistikler hesaplanmış ve sonuçlar Tablo 3 'te gösterilmiştir.

Tablo 3. Okul Öncesi Yaratıcı Sınıf Ortamı Ölçeği sonuçlarına yönelik hesaplanan betimsel istatistikler

\begin{tabular}{|c|c|c|c|c|c|c|}
\hline Ölçek boyutları & $\mathbf{N}$ & $\begin{array}{c}\text { En } \\
\text { Düşük }\end{array}$ & En Yüksek & $\overline{\mathrm{x}}$ & SS & $\begin{array}{l}4 \text { Üzerinden } \\
\text { Ortalama }\end{array}$ \\
\hline Aktif Hale Getirme & 51 & 30,00 & 48,00 & 41,14 & 4,09 & 3,43 \\
\hline Ortam ve Merkezler & 51 & 18,00 & 32,00 & 24,98 & 3,80 & 3,13 \\
\hline Saygı Duyma & 51 & 12,00 & 24,00 & 21,65 & 2,95 & 3,60 \\
\hline Fikirlere Önem Verme & 51 & 6,00 & 12,00 & 10,45 & 1,72 & 3,48 \\
\hline $\begin{array}{l}\text { Okul Öncesi Yaratıcı Sinıf Ortamı } \\
\text { (toplam) }\end{array}$ & 51 & 80,00 & 116,00 & 98,22 & 8,50 & 3,39 \\
\hline
\end{tabular}

Tablo 3'e bakıldığında araştırmaya dahil edilen okullardaki öğretmenlerin görüşlerine göre, sınıf ortamlarının yaratıcılık düzeylerinin oldukça yüksek olduğu görülmektedir $(3,39)$. 
Okullarda sırasıyla en çok çocuklara saygı duyma, çocukların fikirlerine önem verme, aktif hale getirme, ortam ve merkezler boyutlarında yaratıcılığın desteklendiği görülmektedir.

Davies ve diğerleri (2013), İskoçya'da yaratıcı öğrenme ile ilgili 210 adet eğitim materyalini araştırmıştır. $\mathrm{Bu}$ materyallerin yanı sıra yaratıcı öğrenme ortamlarını da incelemişlerdir. Çalışmada, çocuklar ve gençlerde yaratıcılık becerilerinin geliştirilmesinin desteklenmesi için bazı faktörlerin önemi üzerinde durulmuştur. Bu faktörlerden en çok dikkat çekenler; öğretmenler ve çocuklar arasındaki saygı, akran işbirliği için firsatlar, öğrenenlerin çocukların ihtiyaçlarının farkında olmalarıdır. İncelemede ayrıca yaratıcı çevrelerin, çocukların gelişimine ve öğretmenin profesyonelce davranışlarının geliştirilmesine etkisi olduğu bulunmuştur. $\mathrm{Bu}$ doğrultuda yapılan gözlemlerin bu sonuçları destekler nitelikte olduğu söylenebilir. Gözlemler sırasında özellikle ilköğretim bünyesindeki okullarda bulunan materyallerin kısıtlı olduğu, öğretmenlerin çocukların yaratıcı ürünleri konusunda daha çok görselliğe ilişkin kaygılarının olduğu fark edilmiştir. Demiriz’e (2011) göre öğretmenlerin temel görevinin çocukların bilgiye kendi kendilerine yaparak-yaşayarak ulaşabilecekleri zengin uyarıcılarla dolu öğrenme ortamlarını, onların ilgi ve yeteneklerini göz önüne alarak düzenlemek ve bu ortamlar içerisinde yeni bilgileri öğrenmelerine, eksik olanları tamamlamalarına, yanlış olanları düzeltmelerine yardımcı olmaktır. Bu bağlamda Karamustafaoğlu ve Kandaz’ın (2006) yaptıkları çalışmada, okul öncesi öğretmenlerinin etkinliklerini uygularken karşılaştıkları problemler belirlenmiştir. Araştırma sonucunda öğretmenlerin etkinlikleri rahatlıkla uygulayabileceği mekanların, araçgereç ve materyallerin yetersizliği ile ilgili problem yaşadıkları bulunmuştur. Bu sonuçtan yola çıkarak öğretmenlerin çocuklara donanımlı bir çevre sağlamakta zorlandıkları söylenebilir. Ayrıca Ada, Küçükali, Akan, Dal'ın (2014) yaptıkları araştırmada da genel hizmetler olarak ifade edilen sınıf ve bahçe materyalleri ile ilgili öğretmenlerin problem yaşadıklarını belirtmeleri bu sonucu destekler niteliktedir.

Araştırma kapsamında okul öncesi eğitim kurumlarına devam eden çocukların yaratıcılık düzeylerini belirlemek amacıyla üç hikaye ve bir resim tamamlama görevlerinden oluşan HYT kullanılmıştır. Bu bağlamda okul öncesi çocuklarının HYT'de yer alan görevler bazında belirlenen yaratıcı düşünme alt boyutlarından aldıkları puanlara ve toplam puanlara ilişkin betimsel istatistikler hesaplanmış ve sonuçlar Tablo 4'te gösterilmiştir. 
Tablo 4. Hibrit Yaratıcılık Testi sonuçlarına yönelik hesaplanan betimsel istatistikler

\begin{tabular}{lllllll}
\hline Hikayeler & Alt boyutlar & N & En düşük & En yüksek & $\overline{\mathbf{X}}$ & SS \\
\hline \multirow{2}{*}{ 1. Hikaye } & İmgelem & 357 & 0,00 & 7,00 & 2,18 & 1,39 \\
& Esneklik & 357 & 0,00 & 3,00 & 0,61 & 0,64 \\
\hline \multirow{2}{*}{ 2. Hikaye } & Akıcıllk & 357 & 0,00 & 12,00 & 3,51 & 1,94 \\
& Özgünlük & 357 & 0,00 & 1,00 & 0,43 & 0,50 \\
\cline { 2 - 7 } 3. Hikaye & Akıcıllk & 357 & 0,00 & 10,00 & 2,27 & 1,58 \\
2.-3. Hikâye & Özgünlük & 357 & 0,00 & 1,00 & 0,34 & 0,47 \\
\cline { 2 - 7 } & Akıcıllk & 357 & 0,00 & 9,50 & 2,89 & 1,55 \\
& Özgünlük & 357 & 0,00 & 1,00 & 0,39 & 0,40 \\
\cline { 2 - 7 } & Süreklilik & 357 & 0,00 & 3,00 & 0,88 & 0,93 \\
& Tamamlama & 357 & 0,00 & 3,00 & 1,57 & 1,16 \\
Resim Tamamlama & Tema & 357 & 0,00 & 3,00 & 1,10 & 1,25 \\
& Alışllagelmemiş boyut & 357 & 0,00 & 3,00 & 0,26 & 0,58 \\
\hline $\begin{array}{l}\text { Hibrit Yaratıc1lık } \\
\text { Testi (Toplam) }\end{array}$ & & 357 & 0,00 & 23,00 & 10,58 & 4,59 \\
\hline
\end{tabular}

Tablo 4'te elde edilen bulgular incelendiğinde araştırmaya katılan çocukların en çok akıcılık ve imgelem boyutlarındaki yaratıcılıklarının yüksek düzeyde olduğu görülmektedir. Ardından sırasıyla tamamlama, yeni eleman ekleme, süreklilik, tema ve esneklik boyutlarının geldiği, buna karşın özgünlük ve alışılagelmemiş boyutlarında çocukların yaratıcılık düzeylerinin oldukça düşük olduğu belirlenmiştir.

Yaratıcılık eğitiminde çocukların özgün, farklı (alışılagelmemiş boyut) düşünmesi ve değişik ürünler ortaya çıkarması oldukça önemlidir. Özgünlük, yaratıcılığın önemli parçalarından biridir (Runco, Illies ve Eisenman 2005). Bu doğrultuda düşünen çocukların problem çözme ve fikir üretme konusundaki becerileri daha çok gelişmiştir (Runco, Illies ve Eisenman, 2005). Çalışma sırasında araştırmacı tarafından bazı öğretmenlerin yaptıkları etkinliklerde özellikle de sanat etkinliklerinde, tüm çocukları aynı malzemeleri, aynı şekilde kullanarak sınırlı çalışmalar yapmaya yönlendirdiği ve aynı materyallerle farklı ürünler ortaya çıkaran çocukların çalışmalarını düzelttiği gözlenmiştir. $\mathrm{Bu}$ durum, çocukların HYT’nin özgünlük ve alışılagelmemiş alt boyutlarından aldıkları puanların düşüklüğünün sebebi olarak düşünülebilir. 
Yaratıcılığın esneklik ve akıcılık boyutu ise kişinin ortaya çıkan ani değişikleri görebilmesi ve geleneksel problem çözme metodunu terk etmesi şeklinde kısaca açıklanabilir (Dere, 2014). Araştırmaya katılan çocukların akıcılık ve esneklik boyutlarında aldıkları puanların diğer boyutlara göre daha yüksek olduğu görülmektedir. Bu sonuç çocukların fikir üretme konusunda oldukça beceri sahibi olduklarına ancak, orijinal fikir üretme ve bunları geliştirme gibi diğer boyutlarda ortalama düzeyde performans gösterdiklerine işaret etmektedir. Burada çocukların esneklik ve akıcılık boyutlarında yüksek puanlar elde etmeleri, yaratıcılığın alt yapısına ilişkin becerilerin çocuklarda var olduğunu göstermekle birlikte bu potansiyelin çocukların yetenek, ilgi, beceri ve ihtiyaçları doğrultusunda sunulan imkanlarla geliştirilmesi gerektiğine de işaret ettiği düşünülebilir.

HYT'den elde edilen toplam puanlar incelendiğinde, araştırmaya katılan çocukların yaratıcılık testinden almış oldukları puanlar 0,00 ile 23,00 arasında değişiklik göstermektedir. Çocukların yaratıcılık testi ortalama puanları 10,58 $( \pm 4,59)$ olarak hesaplanmıştır. $\mathrm{Bu}$ sonuçlar doğrultusunda çocukların yaratıcılık düzeylerinin orta düzeyde olduğu söylenebilir. Yaratıcı düşünen bireylerin yetiştirilmesi için oluşturulan eğitim ortamlarında yaratıcı düşünmeye yer verilmesi, eğitimin koşullarının kalitesini önemli ölçüde desteklemektedir. Çünkü yaratıcı ortamlar bireylerin öğrenmeye karşı olumlu tutumlar geliştirmelerine yardımcı olmaktadır. Buradan yola çıkarak öğretmenlerin araştırmaya katılan çocuklara nitelikli ortam oluşturmakta zorlandıkları söylenebilir (Tok ve Sevinç, 2012). Çalışma sırasında sınıflarda bulunan bazı öğretmenlerin çocukların farklı çalışmalar yapmalarını teşvik etmeleri yerine tüm sınıfın aynı etkinliği yapmalarında ısrar ettikleri gözlenmiştir. Örneğin, kare elişi kağıtlarla ev yaptırmaya çalışan bir öğretmenin farklı bir ev yapan çocuğun çalışmasını çıkararak tekrar diğer çocukların yaptıkları gibi yapmasını sağlamıştır. Bu sonuçlar öğretmenlerin nitelikli ortam oluşturmada yaşadıkları sorunları ortaya koyan araştırma sonuçları ile benzerlik göstermektedir.

Araştırmaya katılan okul öncesi çocuklarının yaratıcı düşünme düzeyleri ile sınıf ortamlarının yaratıcılık düzeyleri arasındaki ilişkilerin belirlenmesi amacıyla pearson korelasyon katsayısı hesaplanmıştır. Hesaplama sonucu Tablo 5 'te gösterilmiştir. 
Tablo 5. Okul öncesi çocuklarının yaratıcı düşünme düzeyleri ile kurumlarındaki yaratıcı ortamın arasındaki ilişkilerin belirlenmesi amacıyla hesaplanan pearson korelasyon katsayısı sonuçları

\begin{tabular}{|c|c|c|c|c|c|c|c|}
\hline Ölçek & $\begin{array}{l}\text { Değerl } \\
\text { er }\end{array}$ & $\begin{array}{c}\text { Hibrit } \\
\text { Yaratıcilık }\end{array}$ & $\begin{array}{l}\text { Aktif Hale } \\
\text { Getirme }\end{array}$ & $\begin{array}{c}\text { Ortam } \\
\text { Merkezler }\end{array}$ & $\begin{array}{c}\text { Saygi } \\
\text { Duyma }\end{array}$ & $\begin{array}{c}\text { Fikirlere } \\
\text { Önem Verme }\end{array}$ & $\begin{array}{c}\text { Yaratıcı } \\
\text { Sinıf } \\
\text { Ortamı } \\
\text { (Toplam) }\end{array}$ \\
\hline \multirow{3}{*}{$\begin{array}{c}\text { Hibrit } \\
\text { Yaratıcılık } \\
\text { Ölçeği }\end{array}$} & $\mathrm{r}$ & 1 &,- 036 &, $201 * *$ &,- 014 &,- 016 &, $111^{*}$ \\
\hline & $\mathrm{p}$ & &, 503 &, 000 & ,793 &, 760 &, 036 \\
\hline & $\mathrm{n}$ & 357 & 357 & 357 & 357 & 357 & 357 \\
\hline
\end{tabular}

Tablo 5'teki bilgiler incelendiğinde, okul öncesi eğitim kurumuna devam eden çocukların hibrit yaratıc1lk düzeyleri ile kurumlarındaki ortam ve merkezlerin uygun olması $(r=0,201 ; p<0,01)$ ve genel olarak ortamın yaratıcıllğı $(\mathrm{r}=0,111 ; \mathrm{p}<0,05)$ arasında pozitif yönde ancak düşük düzeyde ilişkiler olduğu belirlenmiştir. Çocukların yaratıcı düşünme düzeyleri ile ortamın aktif hale getirilmesi $(\mathrm{r}=-0,036 ; \mathrm{p}>0,05)$, çocuklara saygı duyma $(\mathrm{r}=-0,014 ; \mathrm{p}>0,05)$ ve fikirlere önem verme $(\mathrm{r}=-0,016 ; \mathrm{p}>0,05)$ arasında anlamlı ilişkilerin olmadığı tespit edilmiştir.

Okul öncesi eğitim ortamlarının çocukların gelişimini çok yönlü olarak desteklediği bilinmektedir. Çocukların bulundukları ortamlar çok amaçlı kullanıldığı zaman çocukların yaratıcılıkları da gelişmektedir. Alanyazına bakıldığında da bu bulguyu destekleyen birçok çalışmaya rastlamak mümkündür (Akçum, 2005; Aslan, Aktan ve Kamaraj, 1997; Aral, Köksal Akyol ve Sığırtmaç, 2006; Ceylan, 2008; Çakmak, 2005; Çakmak ve Baran, 2005; Dinçer, 1993; Dursun ve Ünüvar, 2011; Yapıc1, 2002; Yaşar, 2009; Yaşar ve Aral, 2010; Yaşar ve Aral, 2011).

Araştırma bulguları çocukların bulundukları sınıf ortamının yaratıc1lığının onların yaratıcılık düzeyini pozitif yönde ancak düşük düzeyde ilişkili olduğunu göstermekle birlikte bu sonucun öğretmenlerin görüşlerine dayalı olarak sınıf ortamlarının yaratıcılıklarının belirlenmesinde bulundukları sınıf ortamının yaratıcılık düzeyini yüksek görmeye eğilimli olmalarının etkili olduğunu da düşündürmektedir.

Sonuç ne olursa olsun eğitim-öğretim sürecinin devam ettiği ortamlar, öğrenme-öğretme etkinliklerinin meydana geldiği, katılımcılarının birbirleriyle ve bilgiyle iletişim/etkileşim kurduğu çevre anlamına geldiğinden (Karaküçük, 2008) çocukların aktif olarak kullandığı bu çevrenin/ortamların, onların tüm gelişim alanlarını olumlu etkisi olduğunun hatıllanması önemlidir. Kendine güvenen, üreten ve özgün çocuklar yetiştirmek için bu çocukların 
bulundukları ortamların yaratıcı hale getirilmesi ve okul öncesi eğitim programlarında yaratıcılık eğitimine daha çok yer vermesi gerekmektedir. Bu bağlamda Makhmalbaf ve YiLuen Do (2007) ile Pandit ve Neogi‘nin (2016) yaptığı çalışmalarda, okul öncesi dönemdeki çevresel faktörlerin çocukların yaratıcılığı üzerine önemli etkisinin olduğu ve çocuklara zengin materyal, malzeme ve oyuncak sunulan eğitim ortamlarında çocukların yaratıcı düşünmelerinde olumlu yönde değişiklikler meydana geldiği belirlenmiştir (Makhmalbaf ve Yi-Luen Do, 2007). Ancak çocuklar için hazırlanan zengin materyal ve çevreyi çocuklara kaliteli şekilde sunmak da gerekmektedir. Buradan yola çıkarak araştırma kapsamında çocuklara sunulan ortamların öğretmenler tarafından nitelikli kullanımının da önemli olduğu sonucuna ulaşılmıştır. Bu bağlamda çocuk için hazırlanan zengin çevrenin tek başına yeterli olmadığı, oluşturalan zengin ortamın yaratıcı programlarla bütünleştirilerek sunulması gerektiği söylenebilir.

\section{SONUÇ ve ÖNERILER}

Araştırma kapsamında okul öncesi eğitim kurumlarına devam eden çocukların yaratıcılık düzeyleri ile sınıf ortamlarının yaratıcılığg destekleme düzeyi arasındaki ilişki incelenmiştir. Çalışmadan çıkan sonuçlardan biri; okul öncesi eğitim kurumlarına devam eden çocukların yaratıcılıklarının orta düzeyde olduğudur. Yaratıcılık testi alt boyutları açısından çocukların en çok akıcılık ve imgelem boyutlarındaki becerilerinin yüksek olduğu görülmektedir. Ardından sırasıyla tamamlama, yeni eleman ekleme, süreklilik, tema ve esneklik boyutlarının geldiği, buna karşın özgünlük ve alışılagelmemiş boyutlarında çocukların yaratıcılık düzeylerinin oldukça düşük olduğu belirlenmiştir. Bu sonuçların, bazı öğretmenlerin aynı malzemeyi aynı şekilde kullanmaları konusunda tüm çocukları yönlendirmeleri hatta aynı materyallerle farklı ürünler ortaya çıkaran çocukların çalışmalarını düzelterek farklı ürünler ortaya çıkarmalarını engellemeleri neticesinde ortaya çıktığı düşünülmektedir.

Araştırmada ulaşılan diğer bir sonuç ise, araştırmaya dahil edilen öğretmenlerin görüşlerine göre, sınıf ortamlarının yaratıcılık düzeylerinin oldukça yükssek olmasıdır. Bu doğrultuda çalışma grubuna dahil olan okul öncesi eğitim sınıf ortamlarının öğretmen görüşüne dayalı olarak yaratıcı olduğu söylenebilir. Ölçeğin alt boyutları açısından bakıldığında okullardaki öğretmenlerin görüşlerine göre, sınıf ortamlarında yaratıcılığın sırasıyla en çok çocuklara saygı duyma, çocukların fikirlerine önem verme, aktif hale getirme, ortam ve merkezler boyutlarında desteklendiği ortaya çıkmıştır. Bu sonuçlar öğretmenlerin sınıf ortamında en az ortam ve merkezlerin yaratıcılığına önem verdiklerini göstermektedir. 
Araştırmadan çıkan üçüncü sonuç ise, okul öncesi eğitim kurumuna devam eden çocukların yaratıcılık düzeyleri ile sınıf ortamlarının yaratıcılık düzeyi arasındaki ilişkinin pozitif yönde ancak düşük düzeyde olmasıdır. Araştırma bulguları çocukların bulundukları sınıf ortamının yaratıcılığının onların yaratıcılık düzeyini pozitif yönde ancak, düşük düzeyde etkilediğini göstermektedir. Araştırmada öğretmenlerin görüşleri doğrultusunda sınıf ortamının yaratıcılık düzeyinin oldukça yüksek olduğu belirlenmesine karşın bunun çocukların yaratıcılık düzeylerine yeterince yansımadığı görülmektedir. Bu durum, öğretmenlerin sınıf ortamında sundukları yaratıcılığı olduğundan daha olumlu görmeye eğilimli oldukları ve öğretmenlerin sınıf ortamını yaratıcı olarak düzenlediklerini düşünseler de bunun çocuklara yansımasında birtakım problemler yaşandığı şeklinde yorumlanabilir.

\section{Öneriler}

Okul öncesi eğitim kurumuna devam eden çocukların bulundukları sınıf ortamlarının farklı materyaller ile donatılması yaratıcılık açısından oldukça önemlidir. Takmalı oyuncaklar, farklı dokuları içeren ürünler, çocuğun düşünmesini sağlayacak ve denenceler kurmasına yardımcı olacak açık uçlu materyaller vb. bunlardan bir kaçıdır. Dolayısıyla çocukların eğitim aldıkları sınıf ortamlarının zenginleştirilmesi için MEB tarafından maddi destek sağlanması önerilebilir. Öğretmenler kendilerini mesleki olarak yenilemeleri için zaman zaman farklı seminerelere katılmaktadırlar. Bu seminerlerde yeni bilgileri gördükleri gibi eski bilgiler de tazelenmektedir. Buradan yola çıkarak, öğretmenler için gerek yaratıcı ortam düzenlemesi gerekse yaratıcı etkinlikler konusunda çeşitli uygulamalı hizmet içi eğitimler veya seminerler düzenlenebilir. Ayrıca öğretmenlerin özellikle seminer dönemlerinde bir araya gelerek yaratıcı etkinlikler ve yaratıcı ortam düzenlemeye ilişkin iyi örnekler üzerinde tartışmaları, kendi aralarında atölye çalışmaları yapmaları önerilebilir. Bundan sonra yapılacak çalışmalarda çocukların okul ortamlarında bulunan yaratıcılık engellerinin tespit edilmesi ve bu engellerin kaldırılmasına ilişkin araştırmalar planlanabilir. Bununla birlikte okul öncesi eğitim sınıflarında sunulan yaratıcı ortamlar incelenirken çocukların ve öğretmenlerin görüşleri ve performanslarını değerlendiren ölçme araçları ile birlikte gözlemciler tarafından gerçekleştirilen objektif değerlendirmelere de yer verilebilir.

\section{KAYNAKÇA}


Ada, Ş., Küçükali, R., Akan, D., \& Dal, M. (2014). Okul öncesi eğitim kurumlarında yönetim sorunlar1. Middle Eastern and African Journal of Educational Research, 12, 32-49.

Akçum E. (2005). 5-6 Yaş çocuklarının yaratıcılık ve öğrenime hazır oluş düzeylerine okul öncesi eğitimin etkisinin incelenmesi. Yüksek Lisans Tezi, Selçuk Üniversitesi Sosyal Bilimler Enstitüsü, Konya.

Alfuharg1, S. (2015). School environment and creativity development: A review of literature. In society for information. Technology \& Teacher Education International Conference, $1,1832-1837$.

Aslan, E. Aktan, E. \& Kamaraj I. (1997). Anaokulu eğitiminin yaratıcılık ve yaratıcı problemçözme becerisi üzerindeki etkisi M. ̈. Atatürk Eğitim Fakültesi Eğitim Bilimleri Dergisi, 9, 37-48.

Aral, N., Köksal Akyol, A., \& Sığırtmaç, A. (2006). Beş-altı yaş grubundaki çocukların yaratıcılıkları üzerinde Orff öğretisine dayalı müzik eğitiminin etkisinin incelenmesi. Elektronik Sosyal Bilimler Dergisi, 5(15), 1-9.

Ceylan, E. (2008). Okulöncesi eğitime devam eden 5-6 yas çocuklarının bilişsel tempoya göre yaratıcılık düzeylerinin incelenmesi. Yüksek Lisans Tezi, Selçuk Üniversitesi Sosyal Bilimler Enstitüsü, Konya.

Collins, A., O’Connor, E., \& McClowry, S. (2017). The Role of a Temperament Intervention in Kindergarten Children's Standardized Academic Achievement. Journal of Education and Training Studies, 5(2), 120-139.

Çakmak, A. (2005). Anasınıfina devam eden altı yaşındaki köy ve kent çocuklarının yaratıcılıklarının çeşitli değişkenlere göre incelenmesi (Kırıkkale örneği). Yüksek Lisans Tezi, Ankara Üniversitesi Fen Bilimleri Enstitüsü, Ankara.

Çakmak, A., \& Baran, G. (2005). Anasınıfına devam eden altı yaşındaki köy ve kentte yaşayan çocukların yaratıcılıklarının çeşitli değişkenlere göre incelenmesi (Kırıkkale örneği). Ankara Üniversitesi Ev Ekonomisi Yüksek Okulu Bilimsel Araştırma ve Inceleme Yayını Dergisi, 11, 23-48.

Davies D, Jindal-Snape D., Collier C, Digby R, \& Hay P. (2013). Howea creative learning environments in education-A systematic literature review. Thinking Skills and Creativity, 8, 80-91.

Dere, Z. (2014). Anasınıfina devam eden çocuklara uygulanan yaratıcılık ĕgitim programının çocukların yaratıcı davranışlarına etkisinin incelenmesi. Doktora Tezi, Gazi Üniversitesi Eğitim Bilimleri Enstitüsü, Ankara.

Demiriz, S. (2011). Okulöncesi eğitim kurumlarındaki fen ve doğa etkinlikleri ile ilgili uygulamaların belirlenmesi. IV. Fen Bilimleri Eğitimi Kongresi 2000, Bildiriler, Ankara: M.E. s 86. 
Dinçer, D. (1993). Anaokuluna devam eden beş yaş grubu çocukların anne-baba tutumlart ile yaratıcı düşünmeleri arasındaki ilişkinin incelenmesi. Yüksek Lisans Tezi, Marmara üniversitesi Sosyal Bilimler Enstitüsü, İstanbul.

Dursun, M. A., \& Ünüvar, P. (2011). Okulöncesi eğitim döneminde yaratıcılı̆̆ı engelleyen durumlara ilişkin ebeveyn ve öğretmen görüşlerinin incelenmesi. Mehmet Akif Ersoy Üniversitesi Ĕ̈itim Fakültesi Dergisi, 1(21), 110-133.

Duncan, G., Dowsett, C., Claessens, A., Magnuson, K., Huston, A., Klebanov, P. \& Japel, C. (2007). School readiness and later achievement. Developmental Psychology. 43(6), 1428-1446.

Ekici, İ. D. (2014). Öğretmen adaylarının fen öğretiminde yaratıcılığa ilişkin görüşleri ve yaratıcı düşünme etkinliklerini uygulamaya yönelik özyeterlik algıları. Dicle Üniversitesi Ziya Gökalp Eğitim Fakültesi Dergisi, 23, 142-172.

Fleith, S. D. (2000). Teacher and student perceptions of creativity in the classroom environment. Roeper Review, 22(3), 148-153.

Gönen, M., Uzmen, S., Akçin, N., \& Özdemir, N. (1993). Anaokuluna giden 5-6 yaş çocuklarında yaratıcı düşüncenin incelenmesi. Eğitim ve Bilim Dergisi, 17(89) 64-71.

Karamustafaoğlu, S., \& Kandaz, U. (2006). Okul öncesi eğitimde fen etkinliklerinde kullanılan öğretim yöntemleri ve karşılaşılan güçlükler. Gazi Üniversitesi Gazi Eğitim Fakültesi Dergisi, 26(1), 65-81.

Karaküçük, S. A. (2008). Okul öncesi eğitim kurumlarında fiziksel/mekânsal koşulların incelenmesi: Sivas İli Örneği. Sosyal Bilimler Dergisi/Journal Of Social Sciences, $32(2), 307-320$.

Kara, A. (2007). Okul öncesi dönemde 5-6 yas grubu çocukların yaratıcılık düzeylerini etkileyen faktörlere ilişkin ögrretmen görüşleri. Yüksek Lisans Tezi, Selçuk Üniversitesi Sosyal Bilimler Enstitüsü, Konya.

Karasar, N. (2002). Bilimsel araştırma yöntemi, Ankara: Nobel yayınları.

Kemple, K. M. \& Nissenberg. S. A. (2000). Nurturing creativity in early childhood education: families are part of 1t. Working with Families Early Childhood Education Journal, $28(1), 67-71$.

Kim, H. J., Koo, S. S.,\& Lee, K. C. (2015). The mediating effect of their emotional intelligence on the relationship between creative home environment of fathers and creative personality of young children. Journal of the Korea Academia-Industrial cooperation Society. 16(3) 1844-1852.

Lee, K. T. , Lee E. T. (2002). Effective teaching in the information era: Fostering an ICT-based integrated learning environment in schools. Asia-Pacific Journal for Teacher Education and Development, 5(1), 21-45. 
Lew, K. Cho, J (2013). Creativity analysis for smart specialist of the ubiquitous era. International Journal Of Smart Home, 7(4), 183-194.

Leggett, N. (2017). Early Childhood Creativity: Challenging Educators in Their Role to Intentionally Develop Creative Thinking in Children. Early Childhood Education Journal, 6(45), 845-853.

Makhmalbaf, A. \& Yi-Luen, Do E. (2007). Physical environment and creatıvity: Comparıng children's drawing behavior at home and at the bookstore. International Assoc Lation Of Societies Of Design Research The Honkong Polytechnic University, 1-22.

Miles, M. B. \& Hubarmen, A. M. (1994). Qualitative data analysis: A sourcebook. Beverly Hills: Sage Publications.

Oh, M. H., \& Choi, B. G. (2006). Development of a creative home environment scale for preschool children. Journal of the Korean Home Economics Association, 44(1), 1-10.

Özerbaş, M. A. (2011). Yaratıcı düşünme öğrenme ortamının akademik başarı ve bilgilerin

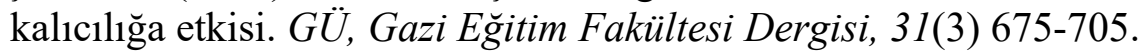

Özmenteş, S. (2012). İlköğretim öğrencilerinin evdeki müziksel ortamları, müzik dersine yönelik tutumları ve kişisel değişkenleri arasındaki ilişkiler. Eğitim ve Bilim Dergisi, 37(163), 53-66.

Pandit, N., \& Neogi, S. (2016). A study on the impact of pre-school factors on creativity of young children. Facilities, 1(30), 271- 231.

Palandökenlier, İ. (2008). İlköğretim sosyal bilgiler dersi çalışma kitaplarında yer alan etkinliklerin yaratıcı düşünme becerisi açısından değerlendirilmesi. Yüksek Lisans Tezi, Çukurova Üniversitesi Sosyal Bilimler Enstitüsü, Adana.

Runco, M. A., Illies, J. J., \& Eisenman, R. (2005). Creativity, originality, and appropriateness: What do explicit instructions tell us about their relationships? The Journal of Creative Behavior, 39(2), 137-148.

Rimm-Kaufman, S. E., \& Pianta, R. C. (2000). An ecological perspective on the transition to kindergarten: A theoretical framework to guide empirical research. Journal of applied developmental psychology, 21(5), 491-511.

Summak, E. G., \& Aydın, Z. (2010). Yaratıcılık ve ulusal eğitim programlarında yaratıcılığa ilişkin araştırmalar. E-Journal Of New World Sciences Academy, 6(1), 362-385.

Sharma, R. (2016). Effect of school and home environments on creativity of children. MIER Journal of Educational Studies, Trends and Practices, 1(2), 38-57.

Tok, E., \& Sevinç, M. (2012). Düşünme becerileri eğitiminin okul öncesi öğretmen adaylarının yaratıcı düşünme becerilerine etkisi. Eğitim ve Bilim, 37(164), 204-222.

Yaşar, M. C., \& Aral, N. (2010). Yaratıcı düşünme becerilerinde okul öncesi eğitimin etkisi. Kuramsal Ĕgitimbilim Dergisi, 3(2), 201-209. 
Yaşar, C. M. (2009). Anasınıfına devam eden altı yaş çocuklarının yaratıcı düşünme becerilerine drama eğitiminin etkisinin incelenmesi. Doktora Tezi, Ankara Üniversitesi Fen Bilimleri Enstitüsü, Ankara.

Yapıcı, M. (2002). Sıfır-beş yas arası çocukların yaratıcılı̆̆ının geliştirilmesinde ailenin rolü. Afyon Kocatepe Üniversitesi Sosyal Bilimler Dergisi, 6(1), 237-245.

Yaşar, M. C., \& Aral, N. (2011). Altı yaş çocuklarının yaratıcı düşünme becerilerine sosyoekonomik düzey ve anne baba öğrenim düzeyinin etkisinin incelenmesi. Kuramsal Eğitimbilim Dergisi, 4(1), 137-145.

Yıldırım, B. (2006). Öğretmenlerin yaratıcılı̆̆a bakış açısı ve anasınıfı çocuklarının yaratıcılık düzeylerinin, ögretmenin yaratıcılık düzeyine göre incelenmesi. Yüksek Lisans Tezi, Hacettepe Üniversitesi sosyal Bilimler Enstitüsü, Ankara.

Yuvacı, Z. (2017). Okul Öncesi eğitim alan 6 yaş çocuklarının yaratıcılık düzeylerinin ögretmenlerinin ve sinıf ortamlarının yaratıcılıklarına göre incelenmesi. Doktora Tezi, Gazi Üniversitesi, Eğitim Bilimleri Enstitüsü, Ankara. 